\title{
The Sources of Foreign Language Speaking Anxiety of Iranian English Language Learners
}

\author{
Firooz Sadighi ${ }^{*}$, Mehdi Dastpak ${ }^{2}$ \\ ${ }^{1}$ Shiraz Branch, Islamic Azad University, Shiraz, Iran \\ ${ }^{2}$ Research Center for Social Determinants of Health, Jahrom University of Medical Sciences, Jahrom, Iran
}

Corresponding author: Mehdi Dastpak, E-mail: Md_dataforse@yahoo.com

\begin{tabular}{l} 
ARTICLE INFO \\
\hline Received: October 04, 2017 \\
Accepted: October 29, 2017 \\
Published: October 31, 2017 \\
Volume: $5 \quad$ Issue: 4 \\
\hline Conflicts of interest: None \\
Funding: None \\
\hline
\end{tabular}

\begin{abstract}
Foreign language learning anxiety is one of the affective factors which influence language learning negatively. It has several sources and different types. The present study aimed at investigating the sources of foreign language speaking anxiety of Iranian EFL learners. To do so, 154 EFL learners participated in the study. They were required to fill out a foreign language anxiety questionnaire which was developed based on the Foreign Language Classroom Anxiety Scale (FLCAS) by Horwitz, Horwitz, and Cope (1986). The results of the study indicated that "fear of making mistakes", "fear of negative evaluation", and "lack of vocabulary knowledge" were the main factors which caused anxiety among students. Some strategies are recommended for the students to use in order to cope with the anxiety-provoking factors.
\end{abstract}

Key words: Affective Factors, Foreign Language Learning Anxiety, Foreign Language Classroom Anxiety Scale

\section{INTRODUCTION}

Learners learning a foreign language are confronted with a lot of problems, including feelings of tension, concern and worries about classroom tasks, such as speech production, listening comprehension, reading texts, composing writing, and so on. It should be noted that most Iranian students often encounter difficulties in their classes when engaging in speaking activities. In fact, these learning barriers may be created from EFL classes. Pérez-Paredez and Martínez-Sánchez (2001) pointed out that the existence of student differences is one of the main reasons behind the problems of those students. To explicate more, among these personal differences, anxiety is one of the most prominent causes which influence language learning negatively (Gardner, 1985). This fact has been integrated with the views of some writers such as Skehan (1989) that individual learners' differences, such as anxiety, are the most important factors in learning foreign languages. In fact, most Iranian EFL students, express dissatisfaction and frustration with language learning. Additionally, Horwitz, Horwitz and Cope (1986) stated that both teachers and students strongly point out that anxiety is related to the conditions in which the language is spoken. Therefore, the need to study such variables in Iranian context is deemed necessary.

Foreign language anxiety (FLA) is one of the emotional factors that affects students' perceptions of foreign language learning negatively. Also, foreign language anxiety is associated with feelings of fear, uncertainty, disorder and concern with the conditions in which the language is learned, such as English as foreign language classes. Foreign language anxiety is defined by MacIntyre and Gardner (1994) as "tension. related to the fields of the second language, including speaking, listening" (p. 284). As stated, it seems that anxiety is limited to speaking and listening which are needed to learn a foreign language. In addition, language anxiety has been identified through two methods; the first one indicates that language anxiety is considered as a fundamental affect, which includes situational factors (MacIntyre, 1995), which occur in any situation, such as social and functional conditions in life. For example, participating in a television contest, interviewing a president, interviewing for a job, etc. This kind of anxiety shows that humans feel embarrassed, frightened and angry in any situation in their lives not only in learning situations. The second approach shows that anxiety is limited to language learning conditions such as classrooms. This kind of anxiety, as Horwitz et al. (1986), called is "specific anxiety". In other words, this kind of anxiety is about problems students face in classroom learning. These problems include the inability of students to understand the input, such as listening and producing output, including speaking in groups and writing a paragraph. This disability is synonymous with anxiety in the classroom, which is considered as a major barrier to language learning. In fact, identifying anxiety through two approaches shows that this is a phenomenon that has many aspects in its nature which is triggered in any general condition, and particular anxiety is triggered by certain conditions in language learning classes. In addition, due to its effects, anxiety leads to stress in ordinary people who have experienced general situations and 
students in terms of language learning in integrated learning classes.

Horwitz et al.'s (1986) theory of FL anxiety is often cited in studies that investigate this issue, since it offers researchers a questionnaire to measure the degree of anxiety in the foreign language classroom (FLCAS). Accordingly, the literature provides sufficient theoretical literature on general language anxiety. However, no empirical studies are specific to FL's anxiety sources, and there are practical recommendations and strategies to deal with them (Tsiplakides \& Keramida, 2009). This study focused on determining the root causes of speaking anxiety in Iranian university students. It specifically aimed at answering this research question:

- What are the main causes of speech anxiety among Iranian EFL students?

\section{LITERATURE REVIEW}

\section{Sources of Language Anxiety}

Speaking a foreign language is a source of anxiety for most students. Research shows different sources of language anxiety. Horwitz et al. (1986) refers to three primary language performance anxieties: "social evaluation", "test anxiety", and "communication apprehension". Yang (1991) identified six sources, including the anxiety of personal and interpersonal relationships, teacher-student interaction, teacher's beliefs about language learning, student beliefs about language learning, classroom techniques, and testing.

Lui (2006: 23-25) examined the causes of anxiety among 98 EFL language learners during their English language classes. He reported the following causes: lack of practice, limited vocabulary knowledge, low level of proficiency, personality, incomprehensible input, fear of committing mistakes, lack of preparation, imperfect grammar, lack of self-confidence, fear of being ridiculed, task difficulty, poor pronunciation, lack of familiarity with peers, lack of familiarity with the subject matter, fear of negative evaluation, fear of being the focus of attention, inability to find suitable words for expressing ideas, inability to express oneself, desire to speak fluently, weak memory, family communication pattern, lack of familiarity with the type of activity, lack of familiarity with the environment, and the fact that English was no their mother tongue.

This appears to be a comprehensive list and so it was used to design the statements of the questionnaire of this study. Most of the above-mentioned factors were reported by 79 EFL female students in Saudi Arabia who took part in Aludwil's study (2014). Yahya (2013) identified the causes of speech anxiety among 104 students at the Arab American University in Palestine. He used the famous scale (FLCAS) to examine three areas that usually affect student communication performance (fear of negative feedback, test anxiety factors, and communication anxiety factors).

The results showed that fear of negative feedback had the highest mean, followed by communication anxiety whereas the test anxiety had the lowest mean. Findings from Subasi's study (2010) that examined the views of 55 Turkish speakers on speech anxiety also confirmed the role of negative evaluation and self-perception of speaking skill in stimulating anxiety. For 149 undergraduates from the University of Sargodha, who took part in Awan et al.' study (2010: 33), "Speaking in front of other students" as the main cause and "worries about making grammatical mistakes", "pronunciation" and "inability to express yourself" were other causes of anxiety. The study of Gaibani and Elmnefi (2014: 114) examined gender role in causing public speaking anxiety among 108 graduate students at EFL at the University of Utara, Malaysia. Most respondents reported that they experienced foreign language speaking anxiety that mad them more frightened and confused. They attributed this to poor speaking ability and lack of self-confidence.

The 74 Iranian students who took part in Mahmoudzadeh's study (2012) attributed their anxiety to the semantic system of their interlanguage. Findings of this study showed that female students were more likely to be anxious than males, and that obtaining more knowledge did not result in significant reduction of speaking anxiety. Ihmuda (2014) conducted a study to examine the effective factors that hinder the learning of Libyan EFL learners. He identified anxiety, fear of committing mistakes and negative evaluation, embarrassment, and lack of self-confidence as effective factors in preventing students from speaking confidently. Genard (2015) reported the majority of the above, adding "poor breathing habits" and "comparing themselves" with others. Hashemi and Abbasi (2013: 641) suggested two other factors: "Adopting or Acquiring Native-like pronunciation" and "formal language classroom setting".

Various factors that trigger speaking anxiety among FL students are related with one another, which make the process too difficult. Insights from psychology and sociology theories can provide FL teachers with strategies to tackle students' speaking anxiety.

Promoting the relationship between students and society is of great significance. The role of the teacher should be to strengthen and coordinate the relationship between the students and their families to support their students to promote their social interaction and communication skills with the community. To support this strategy, researchers such as Bernstein et al. (2008) point out that social phobia sufferers have poor social skills, poor leadership skills, less attention, and more learning disabilities. Therefore, teachers must help their students use learning strategies in order to strengthen their performance (Richards \& Rodgers, 2004).

\section{METHOD}

\section{Participants}

In this study, 154 students ( 74 females and 80 males) in some English language institutes in Shiraz participated whose age ranged from 18 to 30 . They were required to fill out a close-ended questionnaire which was designed for this purpose.

\section{Instrument}

The instrument used in this study was a revised version of the Foreign Language Classroom Anxiety Scale (FLCAS) 
by Horwitz et al. (1986). This questionnaire had 23 items which included most of the possible causes of foreign language speaking anxiety. The students were required to select the options which best matched their views. The questionnaire was scored on a Likert scale from strongly disagree to strongly agree. The frequency of the students' responses to the items of the questionnaire was counted for ranking the main causes of students' foreign language speaking anxiety.

\section{Reliability and validity of the FLCAS}

Foreign Language Classroom Anxiety Scale (FLCAS) has been administered in a number of studies in order to show the anxiety score of a particular group of language learners and it has been shown to be very reliable (Horwitz et al, 1986; Young, 1986; Aida, 1994; Truitt, 1995; Kunt, 1997; Tallon, 2009) and similar to many other researcher such as Cheng, et al 1999 and; Tallon, 2009) who administered the translated version of the FLCAS. In all of these studies FLCAS demonstrates the acceptable level of reliability and validity. For example, in Horwitz et al 's (1986) study with the population of 108 students, the Cronbach's alpha was 0.93 which is a representation of high internal reliability of the scale or In Aida's (1994) study the reliability was reported as 0.80 . Hajizadeh (2013) calculated the internal consistency for her administration of the FLCAS which was 0.84 for 38 Iranian English language learners through the application of Cronbach's alpha formula. The validity of the FLCAS was consulted by three experts in the field and they all reached to the consensus regarding the validity of the FLCAS.

\section{RESULTS}

The result showed that among the possible sources of students' speaking anxiety, the three most significant causes of students" anxiety were "fear of committing mistakes", "fear of being negatively evaluated", and "limited knowledge of vocabulary" respectively. Table 1 provides the results. The percentage of the students' responses to the questionnaire statements is provided in Table 1.

Table 1 indicates that among the possible sources of foreign language speaking anxiety, "fear of making mistakes" was the most significant cause of anxiety (81\%). The next most important causes of anxiety were "fear of being negatively evaluated", and "limited vocabulary knowledge" respectively. Other sources of anxiety can be seen in the table.

\section{DISCUSSION}

Several factors can bring about foreign language speaking anxiety in the classroom. The impact of these factors usually leads to the learners' avoidance of speaking the target language. Thus, instructors are expected to help their students reduce such unfavorable feelings. The first step toward reducing students' anxiety is the identification of the sources of their anxiety. The result of this study provided a range of possible sources of anxiety. Feeling of committing mistakes was found to be the most significant one. This fear is somehow related to the students' fear of being negatively evaluat-
Table 1. Major causes of foreign language speaking anxiety

\begin{tabular}{lcc}
\hline Statement & Percentage & Rank \\
\hline 1. Fear of making mistakes & 81 & 1 \\
2. Fear of being negatively evaluated & 78 & 2 \\
3. Limited Vocabulary Knowledge & 72 & 3 \\
4. Lack of practice & 65 & 4 \\
5. Fear of being the focus of attention & 62 & 5 \\
6. Inability to find proper words to & 59 & 6 \\
express ideas & & \\
7. Lack of confidence & 48 & 7 \\
8. Low English proficiency & 42 & 8 \\
9. Inadequate grammatical & 39 & 9 \\
knowledge & & \\
10. Lack of preparation & 36 & 10 \\
11. Poor/bad pronunciation & 31 & 11 \\
12. Fear of being laughed at & 30 & 12 \\
13. Incomprehensible input & 28 & 13 \\
14. Eagerness or desire to speak & 24 & 14 \\
English fluently & & \\
15. Personality & 19 & 15 \\
16. Difficulty of task & 17 & 16 \\
17. Poor memory & 14 & 17 \\
18. Lack of familiarity with the topic & 12 & 18 \\
19. Inability to express oneself & 9 & 9 \\
20. Family communication pattern & 7 & 20 \\
21. Lack of familiarity with the type \\
of activity & 6 & 21 \\
22. Lack of familiarity with the & & \\
environment & & 23 \\
23. Lack of familiarity with partners/ \\
class
\end{tabular}

ed. A similar study was conducted by Yahya (2013) in which "fear of negative evaluation" was the most significant cause of foreign language speaking anxiety. Ok and Ustaci (2013) conducted a study on Turkish EFL learners. The findings of their study showed that the students preferred not to be corrected by their teachers when they made a mistake while speaking because they believed the corrections made by their teacher were a source of anxiety. However, in Salima's study (2014), the finding was the opposite. In other words, the students believed that they preferred to receive immediate corrective feedback when they made a mistake. They said that immediate feedback would help students improve their oral proficiency.

Another source of FL speaking anxiety was lack of practice. This means that students do not have enough practice in the classroom or outside the classroom. This might be due to teacher-centeredness in Iranian context. Students in the teacher-centered classes do not participate enough and play a minor role in class discussion. A large amount of time is spent on teacher's instruction and explanation of the les- 
son. According to Gan (2012), insufficient opportunities for students' participation can be the main cause of students' weakness in speaking activity. This can be justified by emphasizing the fact that English language in Iranian context is considered as a foreign language and it has a limited communicative use. Therefore, there is not sufficient English input for spoken communication outside the classroom. However, with the advancement of technology and with the advent of English websites this problem can be alleviated.

There is no doubt that establishing good communication requires having enough vocabulary knowledge to express one's feelings and thoughts. Lack of vocabulary knowledge can lead to communication problems and this might bring about speaking anxiety. Failing to find suitable words can cause embarrassment. Therefore, teachers should teach their students to use strategies in order to develop their vocabulary knowledge. Students can develop their vocabulary knowledge through explicit lexical instruction, acquisition of decontextualized lexis, using short stories in the class, etc.

\section{CONCLUSION}

Foreign language speaking anxiety is a vital issue and has a remarkable impact on the development of students' speaking skill. It is associated with feelings of discomfort which causes the students to avoid speaking the target language. As mentioned above, there are several sources of foreign language speaking anxiety among which fear of making mistakes was the most significant one. In addition, foreign language contexts do not provide the students with the chance of practicing the language outside the classroom. Teachers are expected to help students overcome this feeling of uneasiness and nervousness via effective strategies. Students must be encouraged to speak in public places and teachers should utilize learner-centered strategies and establish rapport with their students through problem-solving activities, role-play, and group discussion.

\section{Recommendations for alleviating anxiety levels of EFL students}

Anxiety is one of the factors that inhibits students' focus on learning English as a foreign language. Several strategies can be used to reduce students' anxiety in speaking English inside or outside the classroom. Teachers should create a warm atmosphere in classrooms. In fact, the appreciation of students' feelings increases their willingness and courage to engage in speaking tasks. In addition, teachers must respect their students. One of the approaches for reducing students' anxiety is appreciating students as the center of learning and teaching process. Teachers should give students enough time to express themselves. Teachers should build their students' self-confidence through encouragement. Teachers must provide their students with sufficient input. They should also make use of students' L1 in order to decrease their anxiety. They should let their students speak in their native language whenever they fail to remember the equivalent form of a word in the target language. This can eliminate their psychological barriers. Reducing the noise in and around the class- room can help students learn more effectively. Anxiety can also be reduced by raising students' awareness and knowledge of foreign cultures, reducing the level of social anxiety by reinforcing attachment styles with the social environment and increasing students' desire to communicate with foreign languages and cultures. Actually, social anxiety is a fear of negative evaluation by others. To mitigate such a problem, students can be made aware of the effects of different attachment styles on the promotion or reduction of social anxiety levels (Erozkan, 2009). Attachment Theory (Erozkan, 2009, p.835) says: "An experience of healthy attachment can cause a child to feel that the world is a safe and accepted place in which he fulfills his value causing him to have a high self-esteem., self-esteem and high self-esteem." These styles are, secure, dismissing, preoccupied or dismissed. Social anxiety is positively correlated with fearful rejection and negative correlated with 'secure' style (Erozkan, 2009). Based on the theory of attachment, an appropriate attachment style helps students feel secure and have self-esteem that allows them to establish communicative relationships in their communities.

\section{REFERENCES}

Aida, Y. (1994). Examination of Horwitz, Horwitz, and Cope's construct of foreign language anxiety: The case of students of Japanese. The modern language journal, 78(2), 155-168.

Awan, R.N., Anwar, M.N.,\&Naz, A. (2010).An investigation of foreign language classroom anxiety and its relationship with students' achievement. Journal of College Teaching \& Learning, 7(11), 33-40.

Bernstein, G. A., Bernat, D. H., Davis, A. A., \& Layne, A. E. (2008). Symptom presentation and classroom functioning in a nonclinical sample of children with social phobia. Depression and Anxiety, 25(9), 752-760.

Erozkan, A. (2009). The relationship between attachment styles and social anxiety: An investigation with Turkish university students. Social Behavior and Personality: an international Journal, 37(6), 835-844.

Gaibani, A., \& Elmenfi, F. (2014). The role of gender in influencing public speaking anxiety. British Journal of English Linguistics, 2(3), 7-13.

Gan, Z. (2012). Understanding L2 Speaking Problems: Implications for ESL Curriculum Development in a Teacher Training Institution in Hong Kong. Australian Journal of Teacher Education, 37(1), 43-59.

Gardner, R. C. (1985). Social psychology and second language learning: The role of attitude and motivation. London: Edward Arnold.

Genard, G. 2015. 10 causes of speech anxiety that create fear of public speaking. Retrieved from http://www.genardmethod.com/blog-detail/view/80/10-causes-of-speechanxiety-that-create-fear-of-public-speaking\#.Via3N

Hajizadeh, A. (2013). Investigating Iranian university students' perception of foreign language anxiety (Doctoral dissertation, Eastern Mediterranean University (EMU)Doğu Akdeniz Üniversitesi (DAÜ).).

Hashemi, M., \& Abbasi, M. (2013). The role of the teacher in alleviating anxiety in language classes. International 
Research Journal of Applied and Basic Sciences, 4(3), 640-646.

Horwitz, E. K., Horwitz, M. B., \& Cope, J. (1986). Foreign language classroom anxiety. The Modern language journal, 70(2), 125-132.

Ihmuda, M. S. (2014). Exploring factors that inhibit EFL learners from speaking English effectively: a case study of Libyan students (Master's thesis), University of Malta.

Kunt, N. (1997). Anxiety and belief about language learning a study of Turkish university students learning English in North Cyprus (Unpublished PhD dissertation), The University of Texas, Austin.

Liu, M (2006a). Anxiety in EFL classrooms: Causes and consequences. TESL Reporter, 39(1): 13-32.

MacIntyre, P. D. (1995). How does anxiety affect second language learning? A reply to Sparks and Ganschow. The Modern Language Journal, 79(1), 90-99.

MacIntyre, P. D., \& Gardner, R. C. (1994). The subtle effects of language anxiety on cognitive processing in the second language. Language learning, 44(2), 283-305.

Mahmoodzadeh, M. (2012). Investigating Foreign Language Speaking Anxiety within the EFL Learner's Interlanguage System: The Case of Iranian Learners. Journal of Language Teaching \& Research, 3(3).

Ok, A. S. (2013). Preferences of ELT students on the strategies instructors use in the correction of oral grammar errors. International Journal of Business and Social Science, 4(8).

Pérez-Paredes, P. F., \& Martínez-Sánchez, F. (2000). A Spanish version of the foreign language classroom anxiety scale: revisiting Aida's factor analysis. Revista Española de Lingüística Aplicada RESLA, 14, 337-352.

Richards, J. C., \& Rodgers, T. S. (2014). Approaches and methods in language teaching. Cambridge: Cambridge University Press.

Salima, A. (2014). Teachers' Oral Feedback Impact on EFL Students' Oral Proficiency: Case of Undergraduate Classes of the English Branch at Mku-Biskra. Global IIIuminators. Retrieved from http://creativecommons. org/licenses/by-nc-nd/4.0.

Skehan, P. (1991). Individual differences in second language learning. Studies in second language acquisition, 13(2), 275-298

Subaş1, G. (2010). What are the main sources of Turkish EFL students' anxiety in oral practice? Turkish Online Journal of Qualitative Inquiry, 1(2), 29-49.

Tallon, M. (2009). Foreign language anxiety and heritage students of Spanish: A quantitative study. Foreign Language Annals, 42(1), 112-137.

Truitt, S. N. (1995). Anxiety and beliefs about language learning: A study of Korean university students learning English (Doctoral dissertation, University of Texas at Austin).

Tsiplakides, I., \& Keramida, A. (2009). Helping students overcome foreign language speaking anxiety in the English classroom: Theoretical issues and practical recommendations. International Education Studies, 2(4), 39.

Yahya, M. (2013). Measuring speaking anxiety among speech communication course students at the Arab American University of Jenin (AAUJ). European Social Sciences Research Journal, 1(3), 229-248.

Young, D. J. (1991). Creating a low-anxiety classroom environment: What does language anxiety research suggest? Modern Language Journal, 75, 426-437.

Young, D. J. (1986). The relationship between anxiety and foreign language oral proficiency ratings. Foreign Language Annals, 19(5), 439-445. 